\title{
Methanation of Syngas over Ni-Based Catalysts with Different Supports
}

\author{
Buyan-Ulzii Battulga, Munkhdelger Chuluunsukh, Enkhsaruul Byambajav \\ Laboratory of Clean Energy Technology Development, School of Arts \& Sciences, National University of Mongolia, Ulaanbaatar, \\ Mongolia \\ Email: battulgabuyanaa@gmail.com
}

How to cite this paper: Battulga, B.-U., Chuluunsukh, M. and Byambajav, E. (2020) Methanation of Syngas over Ni-Based Catalysts with Different Supports. Advances in Chemical Engineering and Science, 10, 113-122.

https://doi.org/10.4236/aces.2020.102008

Received: March 18, 2020

Accepted: April 25, 2020

Published: April 28, 2020

Copyright $\odot 2020$ by author(s) and Scientific Research Publishing Inc. This work is licensed under the Creative Commons Attribution International License (CC BY 4.0).

http://creativecommons.org/licenses/by/4.0/

\begin{abstract}
CO methanation over the $20 \%$ nickel catalyst prepared by impregnation-precipitation method on different supports of commercial $\gamma-\mathrm{Al}_{2} \mathrm{O}_{3}, \mathrm{TiO}_{2}$, $\mathrm{SiO}_{2}$ and nano- $\gamma-\mathrm{Al}_{2} \mathrm{O}_{3}{ }^{*}$ was investigated. The nano- $\gamma-\mathrm{Al}_{2} \mathrm{O}_{3}{ }^{*}$ support was pulverized using a ball milling method. Catalyst characterization was done using the methods of BET, XRD, SEM, ICP-OES methods. Carbon monoxide methanation process was carried out at the temperature of $350^{\circ} \mathrm{C}$ in pressure of 3 bar of $\mathrm{H}_{2}$ : $\mathrm{CO}$ syngas with the molar ratio of 3:1 and with the GHSV of $3000 \mathrm{~h}^{-1}$ in a fixed bed reactor. The initial temperature of methane formation increased according to the order of $\mathrm{Ni} / \gamma-\mathrm{Al}_{2} \mathrm{O}_{3}{ }^{*}<\mathrm{Ni} / \mathrm{SiO}_{2}<\mathrm{Ni} / \gamma-\mathrm{TiO}_{2}<$ $\mathrm{Ni} / \gamma-\mathrm{Al}_{2} \mathrm{O}_{3}$. The $\mathrm{Ni} / \gamma-\mathrm{Al}_{2} \mathrm{O}_{3}^{*}$, which was prepared on the surface of nano milled $\gamma-\mathrm{Al}_{2} \mathrm{O}_{3}$ support, produced methane from the lowest temperature of $178^{\circ} \mathrm{C}$ to $350^{\circ} \mathrm{C}$ in $\mathrm{CO}$ methanation. The $\mathrm{Ni} / \gamma-\mathrm{Al}_{2} \mathrm{O}_{3}{ }^{*}$ catalyst gave the highest amount of methane $(0.1224 \mathrm{mmol} / \mathrm{g}$-cat $)$ for $1 \mathrm{~h}$ methanation among other catalysts. XRD and SEM analysis proved that $\mathrm{NiO}$ particles in the $\mathrm{Ni} / \gamma-\mathrm{Al}_{2} \mathrm{O}_{3}{ }^{*}$ were finely distributed, and their sizes were smaller compared to those in the traditional one. The pulverization of $\gamma-\mathrm{Al}_{2} \mathrm{O}_{3}$ improved the dispersion of catalytic active nickel species inside porosity of the support leading to the improvement of its catalytic performance for $\mathrm{CO}$ methanation.
\end{abstract}

\section{Keywords}

$\mathrm{CO}$ Hydrogenation, Water-Gas Shift Reaction, Nano- $\gamma-\mathrm{Al}_{2} \mathrm{O}_{3}$, Methane Productivity

\section{Introduction}

Synthetic natural gas (SNG) as a clean energy carrier has been attracted increasing attention worldwide owing to its lower emissions of sulfur, nitrogen and dust 
than that of direct using coal and is expected to be one of the main energy sources in the $21^{\text {st }}$ century [1]. This process mainly includes coal gasification to syngas and methanation of syngas, in which methanation is a critical step with the reactions as shown in Equation (1) and Equation (2) [2].

$$
\begin{array}{r}
\mathrm{CO}+3 \mathrm{H}_{2} \rightarrow \mathrm{CH}_{4}+\mathrm{H}_{2} \mathrm{O} \Delta \mathrm{H}=-206 \mathrm{~kJ} / \mathrm{mol} \\
\mathrm{CO}_{2}+4 \mathrm{H}_{2} \rightarrow \mathrm{CH}_{4}+2 \mathrm{H}_{2} \mathrm{O} \Delta \mathrm{H}=-165 \mathrm{~kJ} / \mathrm{mol}
\end{array}
$$

Rhodium, ruthenium and nickel are known to be catalytically active for $\mathrm{CO}$ and $\mathrm{CO}_{2}$ methanation reaction. However, nickel is estimated as the most suitable commercial catalyst because of its reasonable cost and high selectivity [3] [4] [5]. The activity of $\mathrm{Ni}$ based catalyst can be affected by support types, preparation methods and promoters [6]-[13]. $\mathrm{MgO}, \mathrm{Al}_{2} \mathrm{O}_{3}, \mathrm{SiO}_{2}, \mathrm{TiO}_{2}$ and $\mathrm{ZrO}_{2}$ are used as a catalyst support for $\mathrm{Ni}$ catalyst in methanation; and these supports can affect the activities of methanation catalyst through changing the particles size and distribution of $\mathrm{Ni}$ active component [6]. Takenaka et al. [10] reported that the activity of supported $\mathrm{Ni}$ catalysts for $\mathrm{CO}$ methanation was strongly dependent on the type of catalytic supports, and the observed conversions of $\mathrm{CO}$ at $526 \mathrm{~K}$ were higher in the order of $\mathrm{Ni} / \mathrm{MgO}<\mathrm{Ni} / \mathrm{Al}_{2} \mathrm{O}_{3}<\mathrm{Ni} / \mathrm{SiO}_{2}<\mathrm{Ni} / \mathrm{TiO}_{2}<\mathrm{Ni} / \mathrm{ZrO}_{2}$ [8]-[14]. Also, Liu et al. [15] showed that when the supports of $\mathrm{Al}_{2} \mathrm{O}_{3}, \mathrm{CeO}_{2}$ and $\mathrm{ZrO}_{2}$ were tested at low temperature of $\mathrm{CO}$ methanation, catalytic activity of $\mathrm{Ni}$ increased according to the order of $\mathrm{Ni} / \mathrm{CeO}_{2}<\mathrm{Ni} / \mathrm{ZrO}_{2}<\mathrm{Ni} / \gamma-\mathrm{Al}_{2} \mathrm{O}_{3}$. The last one presented the best catalytic performance with the highest $\mathrm{CH}_{4}$ selectivity of $94.5 \%$ [15].

In the present study, $\gamma-\mathrm{Al}_{2} \mathrm{O}_{3}, \mathrm{TiO}_{2}, \mathrm{SiO}_{2}$ were selected as a catalyst support for nickel in CO methanation. Since it is supposed that catalyst support should be an important factor for the preparation of fine species of $\mathrm{Ni}$ active catalysts, we tested a pulverization of $\gamma-\mathrm{Al}_{2} \mathrm{O}_{3}$ prior to precipitation of active metal to $\gamma-\mathrm{Al}_{2} \mathrm{O}_{3}$ support. This research work described an effect of different supports on nickel distribution and particle size, and also an influence of nano milling of $\mathrm{Ni} / \gamma-\mathrm{Al}_{2} \mathrm{O}_{3}$ support on catalytic performances for CO methanation.

\section{Experimental Method}

Pulverization of $\gamma-\mathrm{Al}_{2} \mathrm{O}_{3}$ support prior to precipitation of $\mathrm{Ni}$ catalyst

Pulverization of $\gamma-\mathrm{Al}_{2} \mathrm{O}_{3}$ was carried out using a high energy planetary ball mill described in Figure 1(a), Figure 1(b). A planetary ball mill (HPM-700, Haji Engineering, Korea), as shown in Figure 1(a), was used to grind the samples in this study. Ball milling process is a mechanical process which relies on an energy released at the point of collision between balls as well as on the high grinding energy created by friction of balls on the wall. As shown in Figure 1(b), zirconia balls with $5 \mathrm{~mm}$ of diameter were placed in a sintered corundum container. When the mill rotates, balls are picked up by mill wall and rotate around the wall due to centrifugal force leading to grinding of material due to frictional effect. There is also reverse rotation of disc with respect to mill which applies centrifugal force in opposite direction leading to transition of balls on opposite walls 

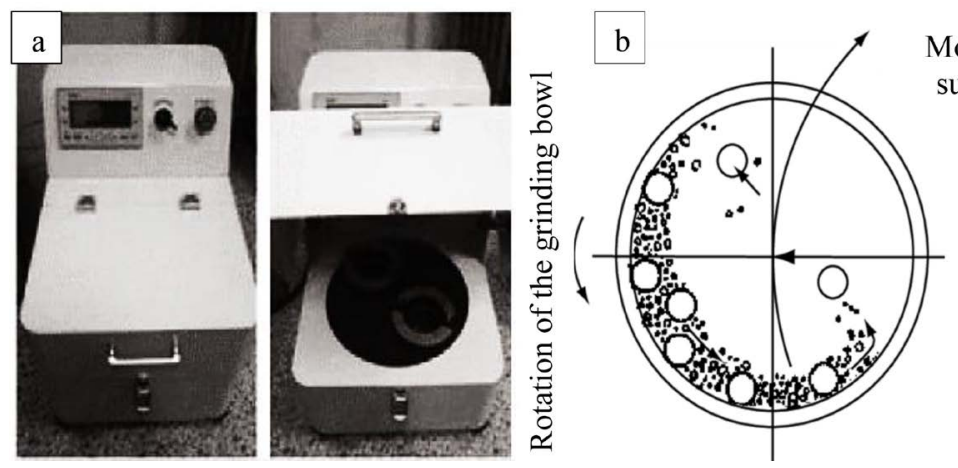

Movement of the supporting disk

Figure 1. Photo of mill (a) and working principle of ball milling process (b).

of mill. The zirconia ball to sample weight ratio was 10:1. A rotation speed of the planet carrier was $500 \mathrm{rpm}$. The pulverization of $\gamma-\mathrm{Al}_{2} \mathrm{O}_{3}$ was performed for 10 min of dry milling.

\section{Catalyst precipitation method}

The different supported Ni catalysts were prepared by impregnation-precipitation method [16] [17] [18]. Initially, catalyst support was dissolved in deionized water of $100 \mathrm{ml}$. The suspension was heated to $50^{\circ} \mathrm{C}$ and maintained at that temperature for $30 \mathrm{~min}$. Amount of $10.11 \mathrm{~g}$ of $\mathrm{Ni}\left(\mathrm{NO}_{3}\right)_{2} \cdot 6 \mathrm{H}_{2} \mathrm{O}$ as a nickel precursor was dissolved in $300 \mathrm{ml}$ of deionized water. A slight excess stoichiometrically of $\mathrm{Na}_{2} \mathrm{CO}_{3}$ aqueous solution with a volume of $300 \mathrm{ml}$ was added dropwise $(\mathrm{pH} \approx 9)$ to the previous solution for precipitation. After stirring continuously for another $1 \mathrm{~h}$ at $50^{\circ} \mathrm{C}$, the carbonate precipitate was removed by filtration, then it is washed by deionized water three times. Then, the precipitate was dried overnight at $110^{\circ} \mathrm{C}$, followed by heating to $500^{\circ} \mathrm{C}$ with a ramp rate of $2^{\circ} \mathrm{C} / \mathrm{min}$ for calcination in air for $4 \mathrm{~h}$. The catalysts were denoted as $\mathrm{Ni} / \gamma-\mathrm{Al}_{2} \mathrm{O}_{3}, \mathrm{Ni} / \gamma-\mathrm{Al}_{2} \mathrm{O}_{3}{ }^{*}$ (nano), $\mathrm{Ni} / \mathrm{TiO}_{2}, \mathrm{Ni} / \mathrm{SiO}_{2}$. All catalysts were pressed into pellets, and then they were further crushed into particles of 45 - 90 mesh, and their activities were evaluated in $\mathrm{CO}$ methanation.

\section{Evaluation of catalyst performance}

Catalytic test for CO methanation was carried out in a stainless steel tubular reactor with the inner diameter of $8 \mathrm{~mm}$. About $1 \mathrm{~g}$ catalyst was used for each test. Catalysts were activated in a hydrogen flow of $13 \mathrm{ml} / \mathrm{min}$ at $400^{\circ} \mathrm{C}$ with a heating rate of $5^{\circ} \mathrm{C} / \mathrm{min}$ for $2 \mathrm{~h}$. After activation, a feed syngas with a volume ratio of $3 \mathrm{H}_{2}: 1 \mathrm{CO}$ was introduced to the reactor, and its flow rate was controlled by an MFC. Methanation was performed at pressure of 3 bar and with a GHSV of $3000 \mathrm{~h}^{-1}$ in the temperature of $350^{\circ} \mathrm{C}$. Gas products were separated through a cooler, and analyzed online by a gas chromatography (GC; YL-6100) with a thermal conductivity detector (TCD). The $\mathrm{CO}$ conversion, $\mathrm{CH}_{4}$ yield and selectivity were calculated using the following Equations (3)-(5), respectively.

CO conversion:

$$
X_{\mathrm{CO}}(\%)=\frac{V_{\mathrm{CO}, \text { inlet }}-V_{\mathrm{CO}, \text { outlet }}}{V_{\mathrm{CO}, \text { inlet }}} \times 100
$$


Methane selectivity:

$$
S_{\mathrm{CH}_{4}}(\%)=\frac{V_{\mathrm{CH}_{4} \text {,outlet }}}{V_{\mathrm{CH}_{4}, \text { outlet }}+V_{\mathrm{CO}_{2} \text {,outlet }}+V_{\mathrm{H}_{2} \text {,outlet }}} \times 100
$$

Methane yield:

$$
Y_{\mathrm{CH}_{4}}(\%)=\frac{X_{\mathrm{CO}} \times S_{\mathrm{CH}_{4}}}{100}
$$

\section{Catalyst characterizations}

BET surface area was measured by nitrogen adsorption at the liquid nitrogen temperature on a Flowsorb III 2305/2310 analyzer. Prior to analysis, the samples were degassed under dynamic vacuum at $150^{\circ} \mathrm{C}$ for $30 \mathrm{~min}$.

XRD measurement was carried out on a mini Flex 600 diffractometer with a monochromatic Co $\mathrm{K} \alpha$ radiations source $(\lambda=1.7903)$. The scans were performed from $5^{\circ}$ to $95^{\circ}$ of $2 \theta$ angle with a step size of $0.02^{\circ}$.

Nickel contents in fresh catalysts were determined using by 6500 ICP-OES analyzer.

SEM images were obtained on the JEOL JSM 7001F microscope operated at 10 - $20 \mathrm{kV}$. The sample was fixed on a carbon black holder with conductive adhesives.

\section{Results and Discussion}

After the impregnation-precipitation, actual contents of nickel catalysts were measured using a method of ICP-OES. Table 1 shows the nominal and experimental contents of nickel metal precipitated on the different supports by the impregnation-precipitation method.

It was identified that when nickel content of the catalysts was nominally expected as $20 \mathrm{wt} \%$, the obtained contents were between in approximately $17-18$ $\mathrm{wt} \%$ depending on different supported catalysts.

Catalyst activity of the $\mathrm{Ni} / \gamma-\mathrm{Al}_{2} \mathrm{O}_{3}{ }^{*}$ catalyst was compared with those of $\mathrm{Ni} / \gamma-\mathrm{Al}_{2} \mathrm{O}_{3}, \mathrm{Ni} / \mathrm{TiO}_{2}$ and $\mathrm{Ni} / \mathrm{SiO}_{2}$ in Figure 2 . Activities of the obtained catalysts prepared on different supports were examined at the reaction temperature of $350^{\circ} \mathrm{C}$ under the syngas pressure of 3 bar.

It was found that $\mathrm{Ni} / \mathrm{SiO}_{2}$ catalyst gave the best activity at the equilibration temperature of $350^{\circ} \mathrm{C}$, and the $\mathrm{CH}_{4}$ yield reached $85.7 \%$. However, the nano- $\mathrm{Ni} / \gamma-\mathrm{Al}_{2} \mathrm{O}_{3}{ }^{*}$ catalyst produced a methane from the lowest temperature fitted around 35 minutes of time on stream. This catalyst gave the $\mathrm{CH}_{4}$ yield of $78.7 \%$ at the equilibration temperature of $350^{\circ} \mathrm{C}$. As shown in Figure 2, the activity of $\mathrm{Ni} / \mathrm{TiO}_{2}$ was similar to that of $\mathrm{Ni} / \gamma-\mathrm{Al}_{2} \mathrm{O}_{3}$.

Table 2 compared the methane yield and the initial temperature of its formation. The initial temperature of methane formation increased according to the order of $\mathrm{Ni} / \gamma-\mathrm{Al}_{2} \mathrm{O}_{3}{ }^{*}<\mathrm{Ni} / \mathrm{SiO}_{2}<\mathrm{Ni} / \gamma-\mathrm{TiO}_{2}<\mathrm{Ni} / \gamma-\mathrm{Al}_{2} \mathrm{O}_{3}$. The $\mathrm{Ni} / \gamma-\mathrm{Al}_{2} \mathrm{O}_{3}{ }^{*}$ produced methane from the lowest temperature of $178^{\circ} \mathrm{C}$ to $350^{\circ} \mathrm{C}$ in $\mathrm{CO}$ methanation. 
Table 1. Nickel contents after precipitation on the different supports by an impregnation-precipitation method.

\begin{tabular}{cccc}
\hline \multirow{2}{*}{ Catalyst code } & Support & Nominal & Ni content, (wt \%) \\
\cline { 3 - 4 } & & 20 & 17 \\
\hline $\mathrm{Ni} / \gamma-\mathrm{Al}_{2} \mathrm{O}_{3}$ & $\gamma-\mathrm{Al}_{2} \mathrm{O}_{3}$ & 20 & 18 \\
$\mathrm{Ni} / \gamma-\mathrm{Al}_{2} \mathrm{O}_{3}^{*}$ (nano) & $\gamma-\mathrm{Al}_{2} \mathrm{O}_{3}$ & 20 & 17 \\
$\mathrm{Ni} / \mathrm{TiO}_{2}$ & $\mathrm{TiO}_{2}$ & 20 & 18 \\
$\mathrm{Ni} / \mathrm{SiO}_{2}$ & $\mathrm{SiO}_{2}$ & & \\
\hline
\end{tabular}

${ }^{1)}$ Determined by ICP-OES analysis.

Table 2. Comparison of $\mathrm{CO}$ methanation performance for $\mathrm{Ni} / \gamma-\mathrm{Al}_{2} \mathrm{O}_{3}, \mathrm{Ni} / \gamma-\mathrm{Al}_{2} \mathrm{O}_{3}{ }^{*}$, $\mathrm{Ni} / \mathrm{TiO}_{2}$ and $\mathrm{Ni} / \mathrm{SiO}_{2}$ catalysts.

\begin{tabular}{ccc}
\hline Catalyst code & $\mathrm{CH}_{4}$ yield, $\%$ & Initial temperature of $\mathrm{CH}_{4}$ formation, ${ }^{\circ} \mathrm{C}$ \\
\hline $\mathrm{Ni} / \gamma-\mathrm{Al}_{2} \mathrm{O}_{3}$ & 75.4 & 268 \\
$\mathrm{Ni} / \gamma-\mathrm{Al}_{2} \mathrm{O}_{3}{ }^{*}$ (nano) & 78.7 & 178 \\
$\mathrm{Ni} / \mathrm{TiO}_{2}$ & 80.4 & 250 \\
$\mathrm{Ni} / \mathrm{SiO}_{2}$ & 85.7 & 218 \\
\hline
\end{tabular}

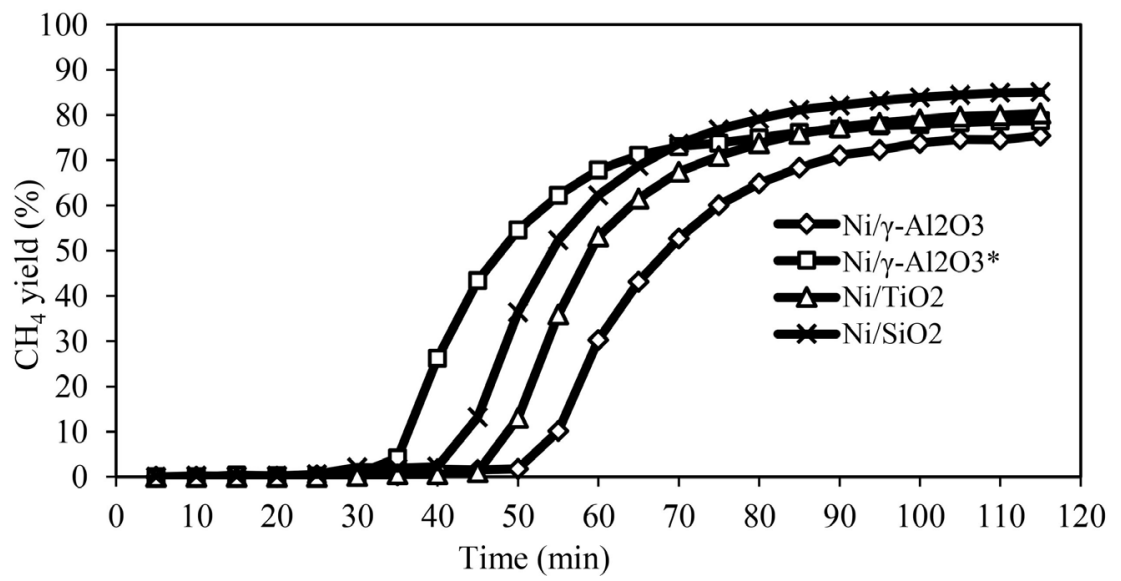

Figure 2. Methane yield obtained during synthesis with the catalysts prepared on different supports.

Activity of $\mathrm{Ni} / \gamma-\mathrm{Al}_{2} \mathrm{O}_{3}{ }^{*}$ prepared with support pulverization was higher than that of traditional $\mathrm{Ni} / \gamma-\mathrm{Al}_{2} \mathrm{O}_{3}$, and the $\mathrm{CH}_{4}$ yield reached $78.7 \%$.

Figure 3 shows that the $\mathrm{Ni} / \gamma-\mathrm{Al}_{2} \mathrm{O}_{3}{ }^{*}$ catalyst converts almost fully the carbon monoxide into methane. In the end of reaction, the content of $\mathrm{CO}$ was only $0.62 \%$ in product gas.

With decreasing the CO content in a feed gas, the methane yield is increasing sharply from 30 minutes to 60 minutes of time on stream, then it was slowly increasing at the equilibration temperature of $350^{\circ} \mathrm{C}$. Regarding temperature program, methanation temperature reaches the equilibration temperature around 60 minutes of time on stream.

Figure 4 shows the $\mathrm{CH}_{4}$ productivities, which were calculated by a sum of 


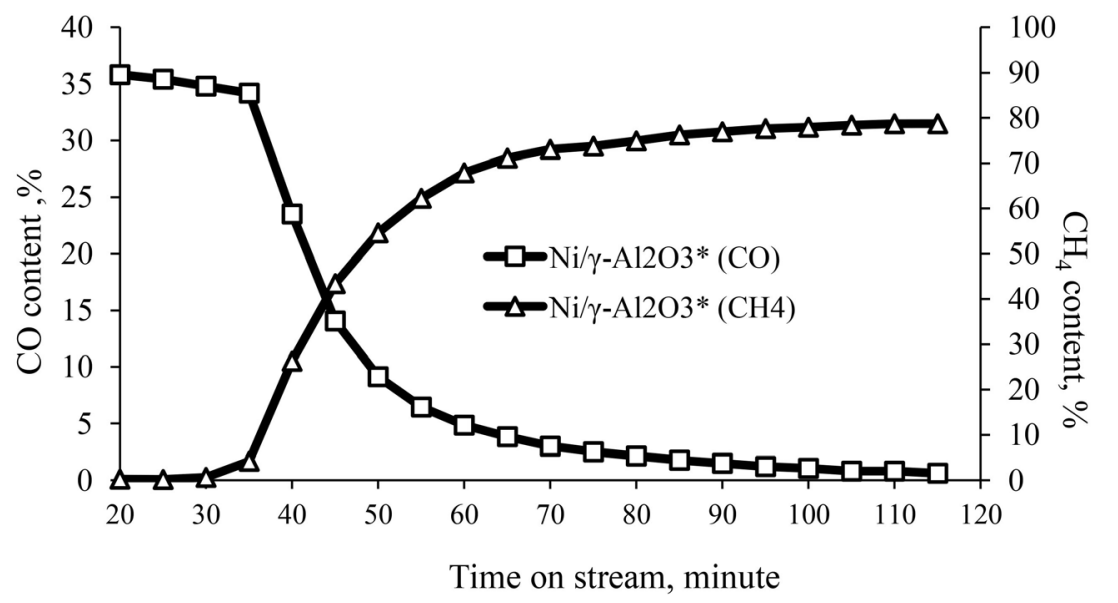

Figure 3. $\mathrm{CO}$ and $\mathrm{CH}_{4}$ contents during methanation synthesis with the $\mathrm{Ni} / \gamma-\mathrm{Al}_{2} \mathrm{O}_{3}{ }^{*}$.

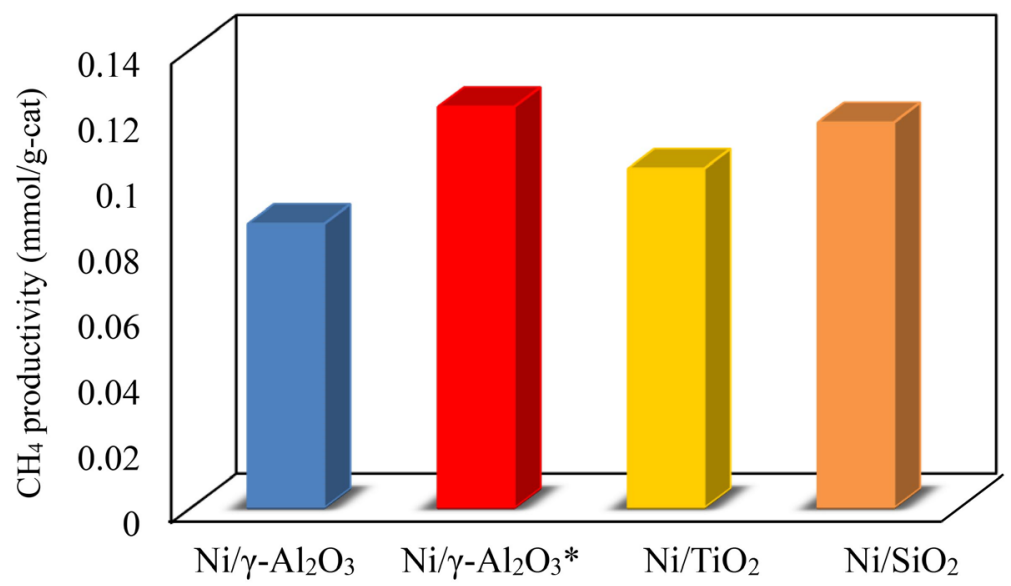

Figure 4. $\mathrm{CH}_{4}$ productivities of $\mathrm{Ni} / \gamma-\mathrm{Al}_{2} \mathrm{O}_{3}, \mathrm{Ni} / \gamma-\mathrm{Al}_{2} \mathrm{O}_{3}{ }^{*}, \mathrm{Ni} / \mathrm{TiO}_{2}$ and $\mathrm{Ni} / \mathrm{SiO}_{2}$ catalysts in $\mathrm{CO}$ methanation at $350^{\circ} \mathrm{C}$.

produced $\mathrm{CH}_{4}$ amount per unit of catalyst weight for $1 \mathrm{~h}$ methanation, with the $\mathrm{Ni} / \gamma-\mathrm{Al}_{2} \mathrm{O}_{3}, \mathrm{Ni} / \gamma-\mathrm{Al}_{2} \mathrm{O}_{3}{ }^{*}, \mathrm{Ni} / \mathrm{TiO}_{2}$ and $\mathrm{Ni} / \mathrm{SiO}_{2}$ catalysts in $\mathrm{CO}$ methanation at $350^{\circ} \mathrm{C}$. It was known that the $\mathrm{Ni} / \gamma-\mathrm{Al}_{2} \mathrm{O}_{3}{ }^{*}$ catalyst produced the highest amount of methane $(0.1224 \mathrm{mmol} / \mathrm{g}$-cat $)$ for $1 \mathrm{~h}$ methanation among the four catalysts. However, the traditional $\mathrm{Ni} / \gamma-\mathrm{Al}_{2} \mathrm{O}_{3}$ catalyst gave the lowest amount of methane $(0.0867 \mathrm{mmol} / \mathrm{g}$-cat $)$ for $1 \mathrm{~h}$ methanation, although it contains the same amount of nickel catalyst as that in the $\mathrm{Ni} / \gamma-\mathrm{Al}_{2} \mathrm{O}_{3}{ }^{*}$ catalyst prepared using the nano milled $\gamma-\mathrm{Al}_{2} \mathrm{O}_{3}$ support. The structures of the two compared catalysts were further analyzed by SEM and XRD analysis.

The SEM images of $\mathrm{Ni} / \gamma-\mathrm{Al}_{2} \mathrm{O}_{3}$ and $\mathrm{Ni} / \gamma-\mathrm{Al}_{2} \mathrm{O}_{3}{ }^{*}$ catalysts are shown in Figure 5(a) and Figure 5(b). As shown in Figure 5(a), there were large crevices and cracks, which were illustrated by dark part of SEM image, on the surface of $\mathrm{Ni} / \gamma-\mathrm{Al}_{2} \mathrm{O}_{3}$. However, Figure 5 (b) shows a uniform porous structure illustrated by bright part for metal oxides in the SEM without any large cracks and crevices. It suggests a formation of fine $\mathrm{Ni}$ nanoparticles distributed on the surface of nano milled $\gamma-\mathrm{Al}_{2} \mathrm{O}_{3}{ }^{*}$ support. The porous structure of the last support provided 



Figure 5. SEM images of the fresh catalysts: (a) $\mathrm{Ni} / \gamma-\mathrm{Al}_{2} \mathrm{O}_{3}$ and (b) $\mathrm{Ni} / \gamma-\mathrm{Al}_{2} \mathrm{O}_{3}{ }^{*}$.

the good dispersion of active nickel catalyst leading to high activity and selectivity for methane. Figure 6 describes the X-ray diffractograms of the fresh catalysts of $\mathrm{Ni} / \gamma-\mathrm{Al}_{2} \mathrm{O}_{3}, \mathrm{Ni} / \gamma-\mathrm{Al}_{2} \mathrm{O}_{3}{ }^{*}, \mathrm{Ni} / \mathrm{TiO}_{2}$ and $\mathrm{Ni} / \mathrm{SiO}_{2}$ before methanation process.

The characteristic diffraction peaks of $\gamma-\mathrm{Al}_{2} \mathrm{O}_{3}$ support and $\mathrm{NiO}$ appear at $53.55^{\circ}$ and $79.59^{\circ}$; and at $43.45^{\circ}, 50.63^{\circ}$ and $74.43^{\circ}$, respectively for the fresh catalysts [16] [17] [18]. For all catalysts prepared by the impregnation-precipitation method, no nickel aluminate species, which were inactive catalytically and non-reducible ones formed by strong interactions between nickel particles and catalyst support, were created in the catalysts. For the $\mathrm{Ni} / \mathrm{SiO}_{2}$ catalyst, two broad diffraction peaks in $2 \theta$ region of $15.5^{\circ}-30.0^{\circ}$ were attributed to the diffraction characteristics of amorphous $\mathrm{SiO}_{2}$. For the $\mathrm{Ni} / \mathrm{TiO}_{2}$ catalyst, the peaks in $2 \theta$ region of $25.3^{\circ}, 43.8^{\circ}, 55.0^{\circ}$ were attributed to the anatase phase of $\mathrm{TiO}_{2}$. The particle sizes were calculated from the Scherrer formula (6) based on the peak width at $50.63^{\circ}$ reflection. The results are listed in Table 3 . Intensity of the peak at $50.63^{\circ}$ of $\mathrm{NiO}$ species in $\mathrm{Ni} / \gamma-\mathrm{Al}_{2} \mathrm{O}_{3}$ was the strongest among other catalysts, even though their nickel contents were similar (see Figure 7). Its $\mathrm{NiO}$ particle size calculated by the Scherrer equation was the largest of $21 \mathrm{~nm}$ among other catalysts. Moreover, Table 3 shows the smaller particles of nickel oxides in $\mathrm{Ni} / \gamma-\mathrm{Al}_{2} \mathrm{O}_{3}{ }^{*}, \mathrm{Ni} / \mathrm{TiO}_{2}$ and $\mathrm{Ni} / \mathrm{SiO}_{2}$ catalysts.

$$
\tau=\frac{K * \lambda}{\beta * \cos \theta}
$$

$$
\begin{aligned}
& \tau \text {-Particle size } \\
& \kappa \text { - Shape factor } \\
& \lambda \text { - X-ray wavelength } \\
& \beta \text {-half the maximum intensity (FWHM) } \\
& \theta \text {-Bragg angle }
\end{aligned}
$$

For the $\mathrm{Ni} / \gamma-\mathrm{Al}_{2} \mathrm{O}_{3}{ }^{*}$ and the $\mathrm{Ni} / \gamma-\mathrm{Al}_{2} \mathrm{O}_{3}$ catalysts, a surface area of catalyst was smaller for the catalyst prepared on the nano milled support of $\gamma-\mathrm{Al}_{2} \mathrm{O}_{3}$. It might be suggested that more fine particles of $\mathrm{NiO}$ species filled inside porous structure of the nano milled support.

Figure 8 shows the $\mathrm{X}$-ray diffractograms of the used $\mathrm{Ni} / \gamma-\mathrm{Al}_{2} \mathrm{O}_{3}, \mathrm{Ni} / \gamma-\mathrm{Al}_{2} \mathrm{O}_{3}{ }^{*}$, 
Table 3. BET surface area and $\mathrm{NiO}$ particle size of the fresh catalysts of $\mathrm{Ni} / \gamma-\mathrm{Al}_{2} \mathrm{O}_{3}$, $\mathrm{Ni} / \gamma-\mathrm{Al}_{2} \mathrm{O}_{3}{ }^{*}, \mathrm{Ni} / \mathrm{TiO}_{2}$ and $\mathrm{Ni} / \mathrm{SiO}_{2}$.

\begin{tabular}{ccc}
\hline Catalyst code & $\mathrm{S}_{\mathrm{BET}}\left(\mathrm{m}^{2} / \mathrm{g}\right)$ & $\mathrm{NiO}$ particle size ${ }^{\mathrm{l})}(\mathrm{nm})$ \\
\hline $\mathrm{Ni} / \gamma-\mathrm{Al}_{2} \mathrm{O}_{3}$ & 131 & 21 \\
$\mathrm{Ni} / \gamma-\mathrm{Al}_{2} \mathrm{O}_{3}{ }^{*}$ (nano) & 115 & 5 \\
$\mathrm{Ni} / \mathrm{TiO}_{2}$ & 23.1 & 14 \\
$\mathrm{Ni} / \mathrm{SiO}_{2}$ & 110 & $<5$ \\
\hline
\end{tabular}

${ }^{1)}$ Calculated from the peak width at $50.63^{\circ}$ using Scherrer equation from XRD.

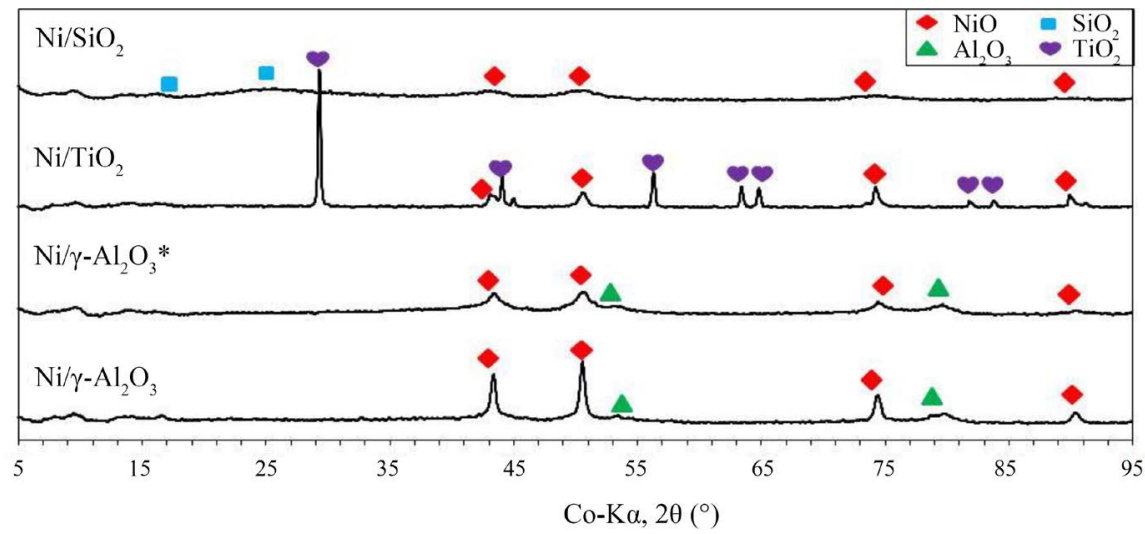

Figure 6. X-ray diffractograms of the obtained catalysts of $\mathrm{Ni} / \gamma-\mathrm{Al}_{2} \mathrm{O}_{3}, \mathrm{Ni} / \gamma-\mathrm{Al}_{2} \mathrm{O}_{3}{ }^{*}$, $\mathrm{Ni} / \mathrm{TiO}_{2}$ and $\mathrm{Ni} / \mathrm{SiO}_{2}$.

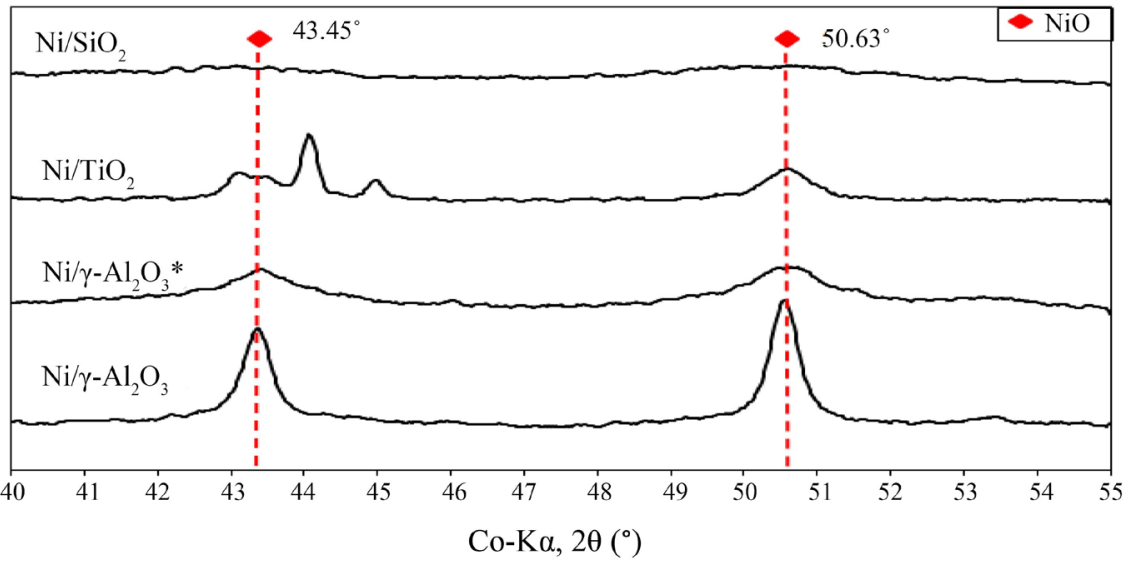

Figure 7. X-ray diffractograms of $\mathrm{NiO}$ particles in the $\mathrm{Ni} / \gamma-\mathrm{Al}_{2} \mathrm{O}_{3}, \mathrm{Ni} / \gamma-\mathrm{Al}_{2} \mathrm{O}_{3}{ }^{*}, \mathrm{Ni} / \mathrm{TiO}_{2}$ and $\mathrm{Ni} / \mathrm{SiO}_{2}$.

$\mathrm{Ni} / \mathrm{TiO}_{2}$ and $\mathrm{Ni} / \mathrm{SiO}_{2}$ catalysts after methanation for $1 \mathrm{~h}$ at $350^{\circ} \mathrm{C}$. It was known that $\mathrm{NiO}$ particles were converted to metal $\mathrm{Ni}$ (peaked around at $50.6^{\circ}$ and $60.9^{\circ}$ ) by hydrogen activation for all catalysts, and there were no compounds of nickel catalysts formed due to catalyst deactivation caused by interaction between metal and support during activation and methanation. As shown in Figure 8, it was also identified that crystallinity of metallic $\mathrm{Ni}$ was very sharp for only the $\mathrm{Ni} / \gamma-\mathrm{Al}_{2} \mathrm{O}_{3}$. It might depend on easy agglomeration of large nickel particles in the $\mathrm{Ni} / \gamma-\mathrm{Al}_{2} \mathrm{O}_{3}$ in the present reaction conditions. 


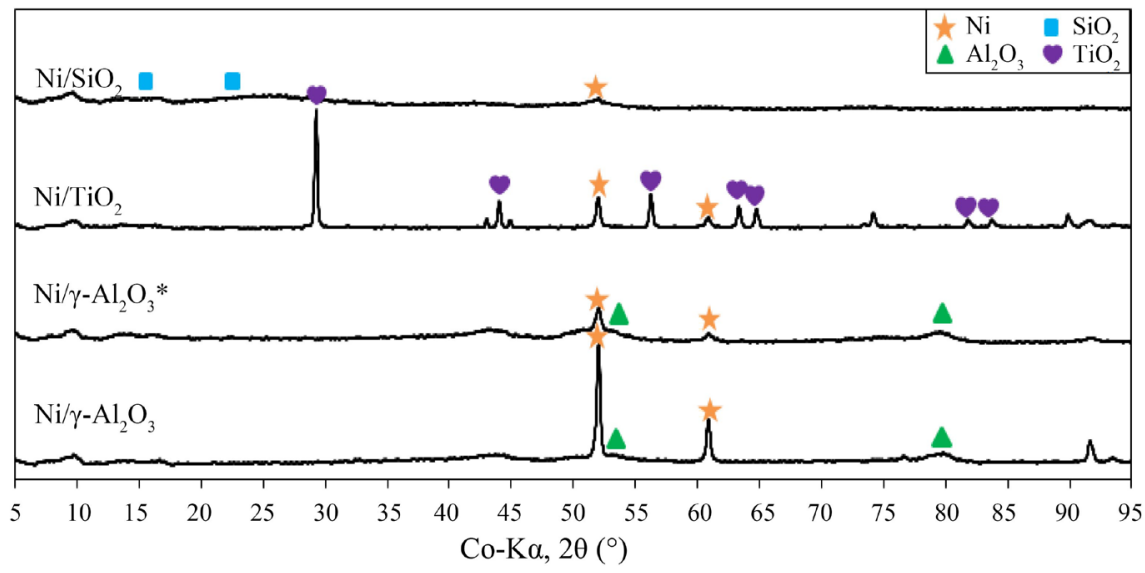

Figure 8. X-ray diffractograms of the used $\mathrm{Ni} / \gamma-\mathrm{Al}_{2} \mathrm{O}_{3}, \mathrm{Ni} / \gamma-\mathrm{Al}_{2} \mathrm{O}_{3}{ }^{*}, \mathrm{Ni} / \mathrm{TiO}_{2}$ and $\mathrm{Ni} / \mathrm{SiO}_{2}$ catalysts after methanation for $1 \mathrm{~h}$.

It is noticeable that the metallic $\mathrm{Ni}$ peak at $50.6^{\circ}$ of $\mathrm{Ni} / \gamma-\mathrm{Al}_{2} \mathrm{O}_{3}{ }^{*}$ catalyst is smaller than $\mathrm{Ni} / \gamma-\mathrm{Al}_{2} \mathrm{O}_{3}$, implying that the pulverization of $\gamma-\mathrm{Al}_{2} \mathrm{O}_{3}$ improved the dispersion of traditional $\mathrm{Ni} / \gamma-\mathrm{Al}_{2} \mathrm{O}_{3}$ catalyst.

\section{Conclusions}

1) The initial temperature of methane formation increased according to the order of $\mathrm{Ni} / \gamma-\mathrm{Al}_{2} \mathrm{O}_{3}{ }^{*}<\mathrm{Ni} / \mathrm{SiO}_{2}<\mathrm{Ni} / \gamma-\mathrm{TiO}_{2}<\mathrm{Ni} / \gamma-\mathrm{Al}_{2} \mathrm{O}_{3}$. The Ni $\gamma-\mathrm{Al}_{2} \mathrm{O}_{3}{ }^{*}$, which was prepared on the surface of nano milled $\gamma-\mathrm{Al}_{2} \mathrm{O}_{3}$ support, produced methane from the lowest temperature of $178^{\circ} \mathrm{C}$ to $350^{\circ} \mathrm{C}$ in $\mathrm{CO}$ methanation.

2) The $\mathrm{Ni} / \gamma-\mathrm{Al}_{2} \mathrm{O}_{3}{ }^{*}$ catalyst gave the highest amount of methane $(0.1224$ $\mathrm{mmol} / \mathrm{g}$-cat) for $1 \mathrm{~h}$ methanation among other catalysts of the traditional $\mathrm{Ni} / \gamma-\mathrm{Al}_{2} \mathrm{O}_{3}, \mathrm{Ni} / \mathrm{SiO}_{2}$ and $\mathrm{Ni} / \gamma-\mathrm{TiO}_{2}$.

3) $\mathrm{XRD}$ and SEM analysis proved that $\mathrm{NiO}$ particles in the $\mathrm{Ni} / \gamma-\mathrm{Al}_{2} \mathrm{O}_{3}{ }^{*}$ were finely distributed, and their sizes were smaller compared to those in the traditional one. The pulverization of $\gamma-\mathrm{Al}_{2} \mathrm{O}_{3}$ improved the dispersion of catalytic active nickel species inside porosity of the support leading to the improvement of its catalytic performance.

\section{Conflicts of Interest}

The authors declare no conflicts of interest regarding the publication of this paper.

\section{References}

[1] Ronsch, S. (2016) Review on Methanation: From Fundamentals to Current Projects. Fuel, 166, 276-296. https://doi.org/10.1016/j.fuel.2015.10.111

[2] Kohei, U., Yuta, T., Yuta, N., Ryuji, K. and Shigeo, S. (2013) Effects of Preparation Conditions of $\mathrm{Ni} / \mathrm{TiO}_{2}$ Catalysts for Selective $\mathrm{CO}$ Methanation in the Reformate Gas. Fuel, 452, 174-178. https://doi.org/10.1016/j.apcata.2012.06.021

[3] Shen, D. and Cheng, C. (2017) Methanation of Syngas $\left(\mathrm{H}_{2} / \mathrm{CO}\right)$ over the Difference Ni-Based Catalysts. Fuel, 189, 419-427. https://doi.org/10.1016/j.fuel.2016.10.122 
[4] Schilidhauer, T.J. (2010) Production of Synthetic Natural Gas (SNG) from Coal and Dry Biomass: A Technology Review from 1950 to 2009. Fuel, 89, 1763-1783. https://doi.org/10.1016/j.fuel.2010.01.027

[5] Song, I.K. (2012) Hydrogenation of Carbon Monoxide to Methane over Mesoporous Nickel-M-Alumina ( $\mathrm{M}=\mathrm{Fe}, \mathrm{Ni}, \mathrm{Co}, \mathrm{Ce}$, and $\mathrm{La}$ ) Xerogel Catalysts. Journal of Industrial and Engineering Chemistry, Fuel, 18, 243-248. https://doi.org/10.1016/j.jiec.2011.11.026

[6] Max-Michael, W., et al. (2008) Walter Lurgi's Methanation Technology for Production of SNG from Coal. Ulrich Berger Lurgi.

[7] Zhang, J., et al. (2014) Low-Temperature Methanation of Syngas in Slurry Phase over Zr-Doped Ni/ $\gamma$ - $\mathrm{Al}_{2} \mathrm{O}_{3}$ Catalysts Prepared Using Different Methods. Fuel, 132, 211-218. https://doi.org/10.1016/j.fuel.2014.04.085

[8] Baowang, L. and Katsuya, K. (2013) Preparation of the Highly Loaded and Well-Dispersed NiO/SBA-15 for Methanation of Producer Gas. Fuel, 103, 669-704. https://doi.org/10.1016/j.fuel.2012.09.009

[9] Mengdie, C., Jie, W., Wei, C., Xueqing, C. and Li, Z.J. (2011) Methanation of Carbon Dioxide on $\mathrm{Ni} / \mathrm{ZrO}_{2}-\mathrm{Al}_{2} \mathrm{O}_{3}$ Catalysts: Effects of $\mathrm{ZrO}_{2}$ Promoter and Preparation Method of Novel $\mathrm{ZrO}_{2}-\mathrm{Al}_{2} \mathrm{O}_{3}$ Carrier. Fuel, 20, 318-324. https://doi.org/10.1016/S1003-9953(10)60187-9

[10] Takenaka, S., Shimizu, T. and Otsuka, K. (2004) Complete Removal of Carbon Monoxide in Hydrogen-Rich Gas Stream through Methanation over Supported Metal Catalysts. International Journal of Hydrogen Energy, 29, 1065-1073. https://doi.org/10.1016/j.ijhydene.2003.10.009

[11] Andrigo, P., Bagatin, R., Pagani, G., et al. (1999) Fixed Bed Reactor. Catalyst Today, 52, 197-221. https://doi.org/10.1016/S0920-5861(99)00076-0

[12] Hoekman, S.K. and Broch, A. (2010) $\mathrm{CO}_{2}$ Recycling by Reaction with Renewably Generated Hydrogen. International Journal of Greenhouse Gas Control, 4, 44-50. https://doi.org/10.1016/j.ijggc.2009.09.012

[13] Mohseni, F. and Magnusson, M. (2012) Biogas from Renewable Electricity: Increasing a Climate Neutral Fuel Supply. Applied Energy, 90, 11-16. https://doi.org/10.1016/j.apenergy.2011.07.024

[14] Barelli, L., Bidini, G., Gallorini, F. and Servili, S. (2008) Hydrogen Production through Sorption-Enhanced Steam Methane Reforming and Membrane Technology: A Review. Energy, 33, 554-570. https://doi.org/10.1016/j.energy.2007.10.018

[15] Liu, Z., Chu, B. and Zhai, X. (2012) Total Methanation of Syngas to Synthetic Natural Gas over Ni Catalyst in a Micro-Channel Reactor. Fuel, 9, 559-605. https://doi.org/10.1016/j.fuel.2011.12.045

[16] Buyan-ulzii, B., Daariimaa, O., Munkhdelger, C., Oyunbileg, G. and Enkhsaruul, B. (2018) Effect of Nickel Precursor and Catalyst Activation Temperature on Methanation Performance. Mongolian Journal of Chemistry, 19, 12-18. https://doi.org/10.5564/mjc.v19i45.1084

[17] Barsbold, K., Buyan-ulzii, B. and Enkhsaruul, B. (2018) Carbon Monoxide Methanation: Effect of Catalyst Preparation Method. Journal of Mongolian Chemical Society, 13, 50-62.

[18] Buyan-ulzii, B., Oyunbileg, G. and Enkhsaruul, B. (2018) Carbon Monoxide Methanation: Effect of Catalyst Preparation Method. Fossil Fuel Chemistry, Processing and Ecology Issue, Ulaanbaatar, 6, 21-29. 